\title{
ANALISIS EFEKTIVITAS DAN EFISIENSI PENYERAPAN ANGGARAN PENDIDIKAN DAN KESEHATAN DALAM APBD KABUPATEN ACEH BESAR PADA PERIODE 2008-2012
}

\author{
Murdani, Ade Suherlan \\ Universitas Sahid Jakarta, UIN Syarif Hidayatullah Jakarta \\ murdani@yahoo.co.id; ade.suherlan@uinjkt.ac.id
}

\begin{abstract}
This study aims to analyze the effectiveness and efficiency of budget absorption level of education and health in the Budget (budget) Aceh Besar district. The analytical method used is the ratio of the effectiveness and efficiency of revenue and expenditure. The results of this study indicate that the level of effectiveness of the education budget absorption is considered ineffective. Level of efficiency in the education budget is less efficient category. The level of effectiveness of health budgets on average less effective. The level of efficiency of the health budget shows less efficient and inefficient. Factors that influence the effectiveness and efficiency of the health sector budget realization that their force major (emergency), the internal condition of the Department of Health, the process of procurement of goods and services that are not timely and not within specifications, on corruption, budget execution document and revision process, an increase in the allocation of expenditure in the Department of Health in the event of changes in the budget, lack of coordination between planning and execution, lack of health budgets
\end{abstract}

Keywords: Effectivity, Efficiency, Local Budget/Regional Budget, Used Budget

\begin{abstract}
Abstrak.
Penelitian ini bertujuan untuk menganalisis efektivitas dan tingkat efisiensi penyerapan anggaran bidang pendidikan dan kesehatan dalam Anggaran Pendapatan dan Belanja Daerah (APBD) Kabupaten Aceh Besar. Metode analisis yang digunakan ialah rasio efektivitas dan efisiensi pendapatan dan belanja. Hasil penelitian ini menunjukkan bahwa tingkat efektivitas penyerapan anggaran bidang pendidikan dinilai tidak efektif. Tingkat efisiensi anggaran pendidikan dalam kategori kurang efisien. Tingkat efektivitas anggaran bidang kesehatan secara rata-rata kurang efektif. Tingkat efisiensi anggaran kesehatan menunjukkan kurang efisien dan tidak efisien. Faktor yang mempengaruhi efektivitas dan efisiensi realisasi anggaran bidang kesehatan yakni adanya kondisi darurat, kondisi internal Dinas Kesehatan, proses pelaksanaan pengadaan barang dan jasa yang tidak tepat waktu dan tidak sesuai spesifikasi, adanya indikasi korupsi, dokumen pelaksanaan anggaran dan proses revisi, adanya peningkatan alokasi belanja di Dinas Kesehatan pada saat terjadi perubahan APBD, lemahnya koordinasi antara perencanaan dan pelaksanaan, minimnya anggaran kesehatan.
\end{abstract}

Kata Kunci: Efektivitas, Efisiensi, Anggaran Daerah, Penyerapan Anggaran 


\section{PENDAHULUAN}

Saat ini, otonomi dalam pembangunan nasional Indonesia telah berjalan dengan cukup baik. Walaupun demikian, pelaksanaan undang-undang Nomor 32 Tahun 2004 tentang Pemerintahan daerah, masih banyak mengalami hambatan. Hal ini disebabkan karena setiap daerah memiliki sumber daya dan kemampuan yang berbeda-beda, sehingga penerapan konsep otonomi ini menimbulkan kesenjangan antar daerah yang relatif tinggi.

Pada pasal 1 butir 5 UU Nomor 32 Tahun 2004 dinyatakan bahwa Otonomi daerah adalah hak, wewenang, dan kewajiban daerah otonom untuk mengatur dan mengurus sendiri urusan pemerintahan dan kepentingan masyarakat setempat sesuai dengan peraturan perundang-undangan. Hal ini mengindikasikan bahwa daerah memiliki kewenangan mengurusi berbagai aspek pembangunan termasuk masalah keuangan.

Berkaitan dengan masalah pengelolaan keuangan di daerah, dengan adanya otonomi daerah maka pengelolaan diharapkan daerah memiliki kemampuan lebih besar dalam peningkatan efektivitas dan efisiensi penggunaan anggarannya bagi sektor-sektor prioritas pembangunan yang dapat dirasakan langsung manfaatnya oleh seluruh lapisan masyarakat di daerah. Untuk mendapatkan hasil yang efektif dan efisien tersebut maka pengelolaan keuangan daerah perlu menjadi prioritas utama setiap pimpinan daerah dalam melaksanakan tugas dan kewajibannya dalam memimpin dan membangun daerahnya. Sektor keuangan sangat krusial dan menjadi masalah yang sangat sensitif, sehingga akuntabilitas pengelolaan perlu menjadi prioritas manajemen keuangan daerah, dimana pimpinan daerah mesti memiliki prosedur perencanaan, pelaksanaan, evaluasi dan pengawasan yang jelas.

Sejalan dengan adanya tuntutan good coorporate governance dan reformasi pengelolaan sektor publik yang ditandai dengan munculnya era baru manajemen publik, dengan tiga prinsip utamanya yang berlaku secara universal yaitu profesional, transparan, dan akuntabel telah mendorong adanya usaha untuk meningkatkan kinerja dibidang pengelolaan keuangan, dengan mengembangkan pendekatan yang lebih sistematis dalam penganggaran sektor publik.

Belanja tidak langsung Kabupaten Aceh Besar pada tahun 2011 mengalami peningkatan dari belanja tidak langsung tahun 2010 dengan rata-rata peningkatan per tahunnya sebesar $15,73 \%$ sedangkan proporsi terhadap belanja APBD rata-rata 
pertahun sebesar 82,31\%. Belanja Langsung Kabupaten Aceh Besar dari tahun 2011 sampai dengan 2012 mengalami penurunan sebesar 13,28\%.

Tabel 1. Perbandingan Anggaran Pendapatan dengan Total Belanja Daerah Kab. Aceh Besar Tahun 2008-2012

\begin{tabular}{lccc}
\hline \multicolumn{1}{c}{ TAHUN } & APBD & TOTAL BELANJA & \multicolumn{1}{c}{ GAP/VARIAN } \\
\hline 2008 & 529.511 .453 .809 & 559.581 .233 .000 & $(30.069 .779 .191)$ \\
2009 & 538.743 .278 .452 & 564.403 .311 .000 & $(25.660 .032 .548)$ \\
2010 & 594.805 .885 .365 & 569.225 .389 .000 & 25.580 .496 .365 \\
2011 & 694.107 .010 .430 & 685.192 .004 .000 & 8.915 .006 .430 \\
2012 & 796.574 .222 .497 & 723.428 .685 .000 & 73.145 .537 .497 \\
\hline
\end{tabular}

Sumber : Data Sekunder diolah, 2013

Selanjutnya, berkaitan dengan efektivitas dan efisiensi penyerapan anggaran dalam APBD Aceh Besar ini terindikasi adanya ketidakefektifan dalam penyerapannya. Jika dikomparasikan antara besarnya anggaran dengan realisasi belanja, maka terdapat varian atau gap yang cukup beragam setiap tahunnya (antara tahun 2008-2012). Secara lengkap dapat dilihat pada Tabel 1.

Tabel 2. Anggaran Pendidikan, Kesehatan, dan Infrastruktur Kabupaten Aceh Besar Tahun 2008-2012

\begin{tabular}{ccc}
\hline \multirow{2}{*}{ Tahun } & \multicolumn{2}{c}{ Total Anggaran (Rupiah) } \\
\cline { 2 - 3 } & Pendidikan & Kesehatan \\
\hline 2008 & $206,129,680,777.00$ & $62,437,405,653.00$ \\
2009 & $199,507,297,461.00$ & $65,153,942,628.00$ \\
2010 & $258,495,937,146.00$ & $64,898,179,087.29$ \\
2011 & $284,109,269,829.00$ & $70,612,177,487.00$ \\
2012 & $342,462,064,320.00$ & $88,269,637,817.00$ \\
\hline Sumber: Dinas pendidikan dan Dinas Kesehatan Kabupaten Aceh Besar, 2013
\end{tabular}

Dari analisis pendahuluan terhadap varian/gap yang ada antara Anggaran Pendapatan dengan Total Belanja Daerah Kab. Aceh Besar Tahun 2008-2012 ini mengindikasikan bahwa penyerapan Anggaran dalam APBD Kab. Aceh Besar tidak efektif, termasuk pada 2 sektor dominan yaitu Pendidikan dan Kesehatan. Terkait dengan efektivitas dan efisiensi penyerapan anggaran, dominasi yang paling besar terletak pada tiga elemen yaitu sektor pendidikan dan kesehatan. Dalam penelitian akan fokus pada efektivitas dan efisiensi penyerapan anggaran pada tiga sektor besar tersebut. Anggaran pendidikan, kesehatan, dan pendidikan di Aceh Besar Tahun 2008-2012 dapat terlihat pada Tabel 2. Sementara ini kondisi penyerapan anggaran pada dua bidang utama ini masih belum optimal serta output yang dihasilkan belum maksimal dalam menciptakan 
kesejahteraan masyarakat. Dalam penelitian ini, peneliti hanya melakukan studi perbandingan tingkat efektivitas dan efisiensi pada lima tahun anggaran terakhir yaitu tahun 2008-2012 karena pada rentang tahun tersebut Kabupaten Aceh Besar tengah melakukan berbagai upaya memaksimalkan penyerapan anggaran dalam APBD guna peningkatan kesejahteraan dan peningkatan pembangunan yang berkelanjutan. Selain itu, pada rentang tahun tersebut periode pemerintahan baru Kabupaten Aceh Besar, sehingga penelitian ini sebagai upaya evaluasi keberhasilan kepemimpinan peride tersebut. Sejalan dengan itu, pada periode 2008-2012 diklaim bahwa pembangunan di Kabupaten Aceh Besar cukup berhasil khususnya pada tiga sektor utama tersebut yaitu bidang pendidikan, dan kesehatan sehingga penelitian ini ingin membuktikan hal tersebut.

Efisiensi merupakan perbandingan antara output dengan input atau dengan istilah lain output per unit input (Mahmudi, 2007). Suatu organisasi apabila mampu menghasilkan output tertentu dengan input serendah-rendahnya, atau dengan input tertentu mampu menghasilkan output sebesar-besarnya (spending well). Efisiensi dapat dijelaskan melalui hubungan antar faktor input yang terbatas dan output yang dihasilkan. Hubungan ini pada dasarnya dapat dievaluasi melalui sudut pandang efisiensi ekonomis dan efisiensi teknis. Efisiensi ekonomis atau efisiensi biaya berkaitan dengan penentuan kombinasi input-input optimal yang dapat merninimumkan biaya produksi suatu tingkat output tertentu.

\section{METODE}

Penelitian ini merupakan jenis penelitian kuantitatif dengan pendekatan deskriptif. Metode pengumpulan data dalam penelitian ini adalah menggunakan teknik wawancara, studi pustaka dan dokumentasi. Untuk mengetahui efisiensi penyerapan anggaran Pendidikan dan Kesehatan di Kabupaten Aceh Besar yaitu teknik analisis rasio efisiensi untuk setiap rincian item pos pengeluaran dengan subkelompok pengeluaran yang bersangkutan, misalnya pengeluaran bidang infrastruktur terhadap belanja pelayanan publik, pengeluaran bidang pendidikan terhadap belanja pelayanan publik, pengeluaran bidang kesehatan terhadap belanja pelayanan publik dan sebagainya.

Untuk menganalisis efektivitas dan efisiensi penyerapan anggaran pendapatan dan belanja pada APBD Kabupaten Aceh Besar menggunakan rasio efektivitas dan 
efisiensi pendapatan dan efisiensi belanja. (Mahmudi, 2010). Rasio ini dirumuskan sebagai berikut:

$$
\text { Rasio Efektifitas }=\frac{\text { Realisasi Penerimaan Pendapatan }}{\text { TargetPenerimaan Pendapatan }} \times 100 \%
$$

Analisis Efisiensi Pendapatan Menghitung analisis efisiensi pendapatan menggunakan rasio efesiensi pendapatan dengan rumus sebagai berikut:

$$
\text { Rasio Efisiensi }=\frac{\text { Pemerolehpendapatan }}{\text { Realisasi Penerimaan Pendapatan }} \times 100 \%
$$

Analisis Efesiensi Belanja Menghitung analisis efisiensi belanja menggunakan rasio efisiensi belanja dengan rumus sebagai berikut:

$$
\text { Rasio Efisiensi }=\frac{\text { Realisasi Belanja }}{\text { Anggaran Belanja }} \times 100 \%
$$

Selain analisis rasio juga digunakan analisis varian dalam mengukur tingkat efisiensi penyerapan anggaran. Analisis Varians (selisih) anggaran pendapatan, dilakukan dengan cara menghitung selisih antara realisasi pendapatan dengan yang dianggarkan. Dalam analisis selisih anggaran pendapatan, hal utama yang perlu dilakukan adalah:

a. Melihat besarnya selisih anggaran pendapatan dengan realisasinya baik secara nominal maupun persentase.

b. Menetapkan tingkat selisih yang dapat ditoleransi atau dianggap wajar

c. Menilai signifikan tidaknya selisih tersebut jika dilihat dari total pendapatan

d. Menganalisis penyebab terjadinya selisih anggaran pendapatan

Tabel 3. Standar Efisiensi Kinerja Pemerintah

\begin{tabular}{cc}
\hline Prosentase Kinerja Pemerintah & Kriteria \\
\hline$<60 \%$ & Sangat Efisien \\
$60 \%-80 \%$ & Efisien \\
$80 \%-90 \%$ & Cukup Efisien \\
$90 \%-100 \%$ & Kurang Efisien \\
$>100 \%$ & Tidak Efisien \\
\hline
\end{tabular}

Metode analisis statistik deskriptif juga digunakan dalam penelitian ini yaitu untuk mengetahui gambaran umum dan kondisi Pemerintah Daerah dan pengelolaan APBD di daerah penelitian sebagai obyek yang diteliti yang lebih penting lagi adalah menempatkan orang-orang secara tepat pula. 


\section{HASIL DAN PEMBAHASAN}

Efektivitas anggaran pembangunan mengukur keberhasilan pemerintah dalam mengalokasikan anggaran pembangunan sesuai dengan tujuan yang telah ditentukan. Ada beberapa cara untuk mengukur keberhasilan tersebut, yaitu dengan melihat seberapa besar pemerintah menentukan alokasi nilai belanja untuk kepentingan publik, seberapa besar nilai belanja untuk kepentingan publik tersebut dapat dimanfaatkan untuk kepentingan publik dengan optimal, dan seberapa besar optimalisasi nilai belanja publik mengakibatkan kegiatan-kegiatan ekonomi ikutan yang bermanfaat bagi masyarakat sehingga menambah kesejahteraan masyarakat.

Untuk menganalisis efektivitas dan efisiensi penyerapan anggaran pendapatan dan belanja pada APBD Kabupaten Aceh Besar menggunakan rasio efektivitas dan efisiensi pendapatan dan efisiensi belanja. (Mahmudi, 2010). Rasio ini dirumuskan sebagai berikut:

$$
\text { Rasio Efektivitas }=\frac{\text { Realisasi Penerimaan Pendapatan }}{\text { Target Penerimaan Pendapatan }} \times 100 \%
$$

\section{Bidang Pendidikan}

Berikut data target anggaran dan realisasi penerimaan anggaran pendidikan di Kabupaten Aceh Besar tahun 2008-2012.

Tabel 4. Besaran Target dan Realisasi Penerimaan Anggaran Pendidikan Kabupaten Aceh Besar Tahun 2008-2012

\begin{tabular}{ccc}
\hline TAHUN & TARGET & REALISASI PENERIMAAN \\
\hline 2008 & $242,981,993,700$ & $206,129,680,777.00$ \\
2009 & $266,678,000,000$ & $199,507,297,461.00$ \\
2010 & $324,528,000,000$ & $258,495,937,146.00$ \\
2011 & $343,389,000,000$ & $284,109,269,829.00$ \\
2012 & 377.727 .900 .000 & $342,462,064,320.00$
\end{tabular}

Sumber: Dinas Pendidikan Kabupaten Aceh Besar, 2013

Dalam bidang pendidikan, dengan menggunakan data yang terdapat pada Tabel 4, maka dapat dihitung rasio efektivitasnya dari tahun ke tahun sebagai berikut:

$$
\begin{aligned}
& \text { Rasio Efektivitas Tahun } 2008=\frac{206,129,680,777}{242,981,993_{7} 700} \times 100 \%=84.83 \% \\
& \text { Rasio Efektivitas Tahun } 2009=\frac{199,507,297,461}{266,678,000,000} \times 100 \%=74.81 \% \\
& \text { Rasio Efektivitas Tahun } 2010=\frac{258,495,937,146}{324,528,000,000} \times 100 \%=79.65 \%
\end{aligned}
$$




$$
\begin{aligned}
& \text { Rasio Efektivitas Tahun 2011 }=\frac{284,109,269,829}{343,389,000,000} \times 100 \%=82.74 \% \\
& \text { Rasio Efektivitas Tahun 2012 }=\frac{42,462,064,320}{377,727,900,000} \times 100 \%=90.66 \%
\end{aligned}
$$

\section{Gambar 1. Rasio Efektivitas Anggaran Pendidikan Kabupaten Aceh Besar Tahun 2008-2012}

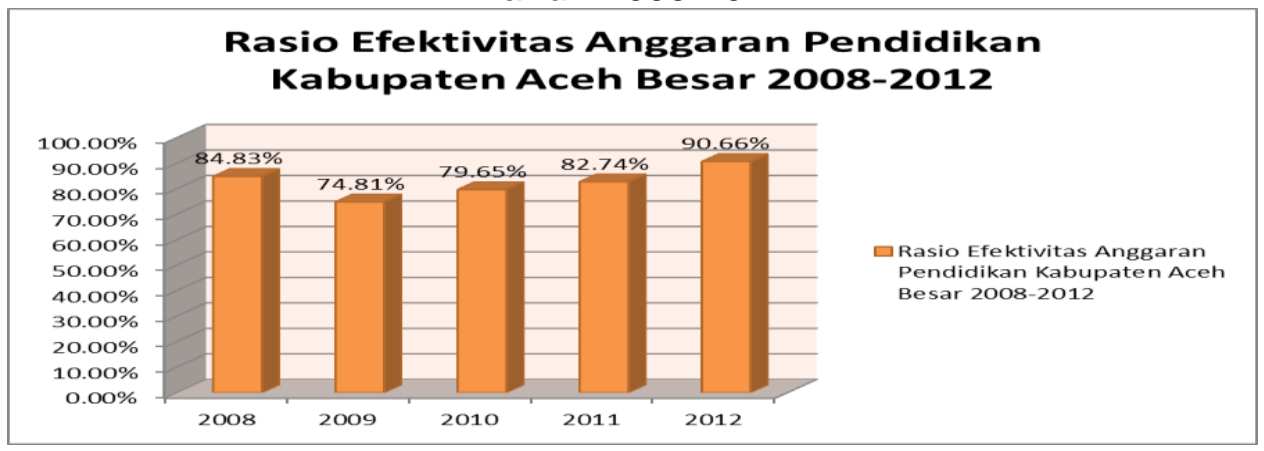

Dari perhitungan dan gambar yang disajikan di atas dapat diketahui bahwa rasio efektivitas anggaran bidang pendidikan dari tahun 2008-2012 bervariasi. Dari gambar terlihat bahwa target penerimaan anggaran bidang pendidikan tidak pernah tercapai secara maksimal setiap tahunnya. Tahun 2008 rasio efektivitas anggaran pembangunan pendidikan di Kabupaten Aceh Besar sebesar $84.83 \%$, artinya bahwa pencapaian target penerimaan anggaran pembangunan bidang pendidikan hanya $84.83 \%$, hal ini disebabkan pada tahun 2008 ini dana otonomi khusus belum diterima pada tahun ini untuk bidang pendidikan. Sementara itu pada tahun 2008 target penerimaan Pendapatan Asli daerah (PAD) hanya mencapai 90\%. Tahun 2009 rasio efektivitas anggaran pembangunan pendidikan di Kabupaten Aceh Besar sebesar $74.81 \%$, kondisi ini menurun drastis dari tahun 2008. Tahun 2010 sebesar rasio efektivitas naik menjadi 79.65\% jika dibandingkan dengan rasio efektivitas tahun 2008. Kondisi ini terus meningkat dimana tahun 2011 menjadi 82.74\% dan tahun 2012 sebesar $90.66 \%$. hal ini menunjukkan bahwa pencapaian target penerimaan di bidang pendidikan terus meningkat.

Apabila dalam tahun anggaran berjalan telah terjadi ketidakefektifan anggaran pendapatan khususnya dalam bidang pendidikan, pemerintah daerah dapat mengurangi program dan kegiatan dengan terlebih dahulu melakukan perubahan terhadap APBD induk melalui mekanisme yang telah diatur dalam Peraturan Menteri Dalam Negeri tentang Pedoman Umum Penyusunan APBD. 


\section{Bidang Kesehatan}

Secara keseluruhan dari tahun ke tahun dapat diketahui bahwa rasio efektivitas bidang kesehatan ini rata-rata kurang efektif, dimana angka rasio secara rata-rata menunjukkan di bawah $60 \%$ pencapaian realisasi penerimaan dari yang ditargetkan, artinya kinerja anggaran sektor kesehatan kurang maksimal. Berikut data target dan realisasi penerimaan anggaran kesehatan tersebut:

Tabel 5. Besaran Target dan Realisasi Penerimaan Anggaran Kesehatan Kabupaten Aceh Besar Tahun 2008-2012

\begin{tabular}{ccc}
\hline TAHUN & TARGET & REALISASI PENERIMAAN \\
\hline 2008 & $123,382,129,660$ & $62,437,405,653.00$ \\
2009 & $115,823,435,556$ & $65,153,942,628.00$ \\
2010 & $119,535,930,000$ & $64,898,179,087.29$ \\
2011 & $119,172,151,400$ & $70,612,177,487.00$ \\
2012 & 117.429 .442 .634 & $88,269,637,817.00$ \\
\hline
\end{tabular}

Sumber: Dinas Kesehatan Kabupaten Aceh Besar, 2013

Jika dihitung dengan menggunakan formula yang sama seperti pada sektor pendidikan, maka diperoleh hasil sebagai berikut:

Rasio Efektivitas Anggaran Kesehatan Tahun 2008

$$
=\frac{62,437,405,653}{123,382,129,660} \times 100 \%=50.6 \%
$$

Rasio Efektivitas Anggaran Kesehatan Tahun 2009

$$
=\frac{65,153,942,628}{115,823,435,556} \times 100 \%=56.25 \%
$$

Rasio Efektivitas Anggaran Kesehatan Tahun 2010

$$
=\frac{64,898,179,087}{119,535,930,000} \times 100 \%=54.29 \%
$$

Rasio Efektivitas Anggaran Kesehatan Tahun 2011

$$
=\frac{70,612,177,487}{119,172,151,400} \times 100 \%=59.25 \%
$$

$$
\begin{aligned}
& \text { Rasio Efektivitas Anggaran Kesehatan Tahun } 2012 \\
& =\frac{88,269,637,817}{117,429,442,634} x 100 \%=75.17 \%
\end{aligned}
$$

\section{Efisiensi Anggaran}

Untuk menganalisis efektivitas dan efisiensi penyerapan anggaran pendapatan dan belanja pada APBD Kabupaten Aceh Besar menggunakan rasio efektivitas dan efisiensi pendapatan dan efisiensi belanja. (Mahmudi, 2010). Analisis Efisiensi 
Pendapatan Menghitung analisis efisiensi pendapatan menggunakan rasio efesiensi pendapatan dengan rumus sebagai berikut:

$$
\text { Rasio Efisiensi }=\frac{\text { PemerolehPendapatan }}{\text { Realisasi Penerimaan Pendapatan }} \times 100 \%
$$

\section{Gambar 2. Rasio Efektivitas Anggaran Kesehatan Kabupaten Aceh Besar Tahun 2008-2012}

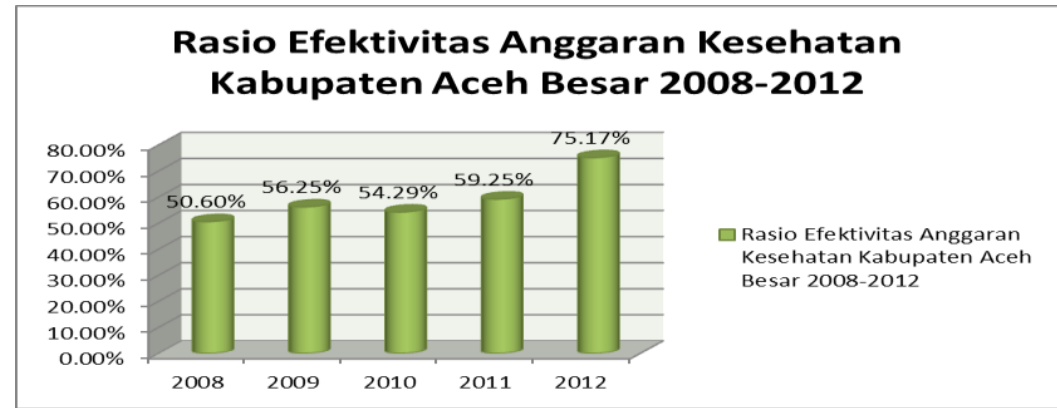

Analisis Efisiensi Belanja Menghitung analisis efisiensi belanja menggunakan rasio efisiensi belanja dengan rumus sebagai berikut:

$$
\text { Rasio Efisiensi }=\frac{\text { Realisasi Belanja }}{\text { Anggaran Belanja }} \times 100 \%
$$

Tabel 6. Standar Efisiensi Kinerja Pemerintah

\begin{tabular}{cc}
\hline Prosentase Kinerja Pemerintah & Kriteria \\
\hline$<60 \%$ & Sangat efisien \\
$60 \%-80 \%$ & Efisien \\
$80 \%-90 \%$ & Cukup efisien \\
$90 \%-100 \%$ & Kurang Efisien \\
$>100 \%$ & Tidak Efisien \\
\hline
\end{tabular}

\section{Bidang Pendidikan}

Berkaitan dengan penyerapan anggaran pada sektor pendidikan dinilai kurang efisien. $\mathrm{Hal}$ ini dapat diketahui dari hasil perhitungan tingkat efisiensi penyerapan anggaran pendidikan dalam rentang waktu tahun 2008 hingga tahun 2012, dimana setiap tahun penyerapan anggaran bidang pendidikan selalu di atas $90 \%$. Jika dilihat pada standar efisiensi kinerja pemerintah masuk pada kategori kurang efisien dengan rentang nilai antara $90-100 \%$. Hal ini disebabkan karena masih bergantung pada basis penyerapan anggaran, dimana anggaran harus terserap sebanyak-banyaknya, jika serapan anggaran tinggi diasumsikan bahwa hal itu mengindikasikan kinerja yang tinggi pula padahal belum tentu demikian. 
Berikut hasil perhitungan rasio efisiensi penyerapan anggaran bidang pendidikan di Kabupaten Aceh Besar tahun 2008-2012, dengan perhitungan menggunakan formula menurut Mahmudi (2010):

Rasio Efisiensi Bidang Pendidikan Tahun 2008

$$
=\frac{205,460,727,488}{206,129,680,777} \times 100 \%=99.68 \%
$$

Rasio Efisiensi Bidang Pendidikan Tahun 2009

$$
=\frac{197,455,885,762}{199,507,297,461} \times 100 \%=98.97 \%
$$

Rasio Efisiensi Bidang Pendidikan Tahun 2010

$$
=\frac{245,067,477,920}{258,495,937,146} x 100 \%=94.81 \%
$$

Rasio Efisiensi Bidang Pendidikan Tahun 2011

$$
=\frac{276,052,165,852}{284,109,269,829} \times 100 \%=97.16 \%
$$

Rasio Efisiensi Bidang Pendidikan Tahun 2012

$$
=\frac{320,633,722,657}{342,462,064,320} \times 100 \%=93.63 \%
$$

Tabel 7. Besaran Alokasi dan Penyerapan Anggaran Pendidikan

\begin{tabular}{ccc} 
& Kabupaten Aceh Besar Tahun 2008-2012 \\
\hline TAHUN & ANGGARAN & PENYERAPAN \\
\hline 2008 & $206,129,680,777.00$ & $205,460,727,488.00$ \\
2009 & $199,507,297,461.00$ & $197,455,885,762.00$ \\
2010 & $258,495,937,146.00$ & $245,067,477,920.00$ \\
2011 & $284,109,269,829.00$ & $276,052,165,852.00$ \\
2012 & $342,462,064,320.00$ & $320,633,722,657.00$ \\
\hline
\end{tabular}

Sumber: Dinas Pendidikan Kabupaten Aceh Besar, 2013

Dapat diketahui dari hasil perhitungan tersebut bahwa semua dinilai kurang efisien karena basis kinerja anggarannya ditentukan oleh tingginya serapan bukan kualitas output dan keluarannya. Rasio efisiensi anggaran pendidikan tahun 2008 sebesar 99.68\%, tahun 2009 sebesar 98,97\%, tahun 2010 sebesar 94, 81\%, tahun 2011 sebesar 97,16\%, dan tahun 2012 sebesar 93, $63 \%$, kondisi ini semua dinilai "kurang efisien", artinya penyerapan anggaran masih mengalami banyak kebocoran, belum menyentuh program yang direncanakan secara maksimal sehingga keluaran dan hasil 
yang dirasakan masyarakat belum maksimal, hanya jumlah nominal anggarannya yang habis, sementara outputnya kurang maksimal.

\section{Gambar 3. Rasio Efisiensi Anggaran Pendidikan Kabupaten Aceh Besar Tahun 2008-2012}

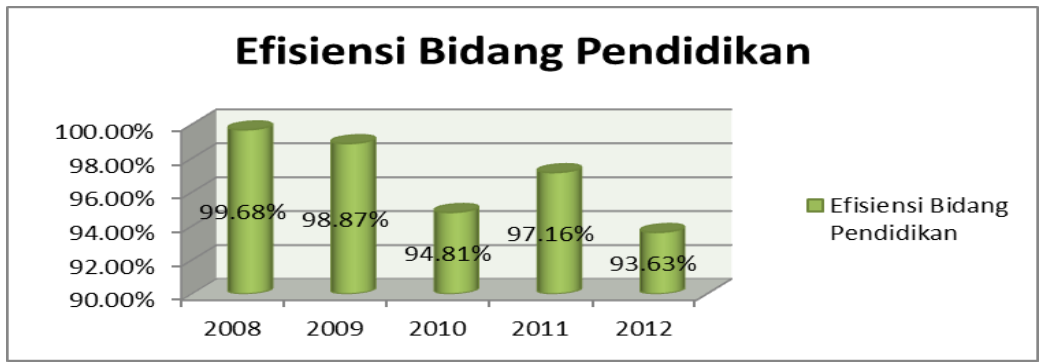

Beberapa faktor yang menyebabkan kurangnya efisiensi ini yaitu: Kurangnya perencanaan yang baik; Korupsi pada sektor pendidikan masih tinggi; Kebocoran dana pembangunan pendidikan masih tinggi; Pungutan liar masih relatif tinggi; Prosedur belanja barang dan belanja modal yang rumit; Penyerapan menumpuk di akhir tahun; Pelaksanaan program terburu-buru karena anggaran baru dapat dicairkan pertengahan tahun anggaran berjalan; dan Ketakutan dan kehati-hatian pengambil kebijakan penggunaan anggaran karena pengawasan yang sangat ketat dan pelaporan yang sangat kaku.

\section{Bidang Kesehatan}

Berikut ini disajikan besarnya alokasi dan penyerapan anggaran bidang kesehatan di Kabupaten Aceh Besar tahun 2008-2012:

Tabel 8. Besaran Alokasi dan Penyerapan Anggaran Kesehatan Kabupaten Aceh Besar Tahun 2008-2012

\begin{tabular}{ccc}
\hline TAHUN & ANGGARAN & PENYERAPAN \\
\hline 2008 & $62,437,405,653.00$ & $59,612,613,354.00$ \\
2009 & $65,153,942,628.00$ & $67,094,529,753.00$ \\
2010 & $64,898,179,087.29$ & $65,662,638,522.00$ \\
2011 & $70,612,177,487.00$ & $69,693,186,496.00$ \\
2012 & $88,269,637,817.00$ & $80,725,609,997.00$ \\
\hline
\end{tabular}

Sumber: Dinas Kesehatan Kabupaten Aceh Besar, 2013

Rasio Efisiensi Bidang Kesehatan Tahun 2008

$$
=\frac{59,612,613,354}{62,437,405,653} \times 100 \%=95.48 \%
$$

Rasio Efisiensi Bidang Kesehatan Tahun 2009

$$
=\frac{67,094,529,753}{65,153,942,628} \times 100 \%=102.98 \%
$$


Rasio Efisiensi Bidang Kesehatan Tahun 2010

$$
=\frac{65,662,638,522}{64,898,179,087} x 100 \%=101.18 \%
$$

Rasio Efisiensi Bidang Kesehatan Tahun 2011

$$
=\frac{69,693,186,496}{70,612,177,487} x 100 \%=98.69 \%
$$

$$
\begin{aligned}
& \text { Rasio Efisiensi Bidang Kesehatan Tahun } 2012 \\
& =\frac{80,725,609,997}{88,269,637,817} \times 100 \%=91.45 \%
\end{aligned}
$$

Dari hasil perhitungan terlihat jelas bahwa setiap tahun penyerapan anggaran bidang kesehatan dalam kategori kurang efisien dan tidak efisien. Beberapa faktor yang menyebabkan kurang dan tidak efisiennya penyerapan anggaran bidang kesehatan di Kabupaten Aceh Besar diantaranya ialah: adanya kondisi darurat, kondisi internal Dinas Kesehatan, proses pelaksanaan pengadaan barang dan jasa yang tidak tepat waktu dan tidak sesuai spesifikasi, adanya indikasi korupsi, dokumen pelaksanaan anggaran dan proses revisi, permasalahan lainnya, seperti adanya peningkatan alokasi belanja di Dinas Kesehatan pada saat terjadi perubahan APBD, lemahnya koordinasi antara perencanaan dan pelaksanaan, dan minimnya anggaran kesehatan.

\section{Gambar 4. Rasio Efisiensi Anggaran Kesehatan Kabupaten Aceh Besar Tahun 2008-2012}

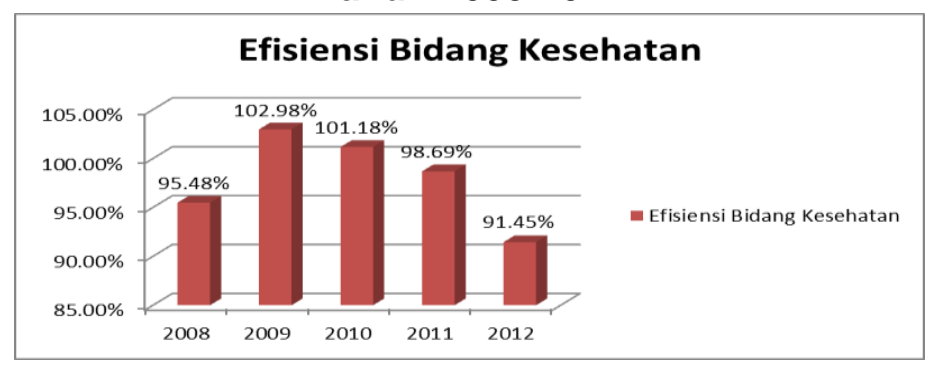

\section{Efektifitas Keluaran}

\section{Bidang Pendidikan}

Realisasi keluaran telah dicapai pada sektor pendidikan selama kurun waktu 20082012 di Kabupaten Aceh Besar. Satuan Kerja Perangkat kabupaten yang melaksanakan urusan pendidikan adalah Dinas dan Kantor Dayah Kabupaten Aceh Besar. Selama kurun waktu 2008-2012 telah merealisasikan berbagai program dan kegiatan bidang pendidikan, yaitu: 
Tabel 9. Realisasi Peningkatan Sarana Prasarana Bidang Pendidikan Kabupaten Aceh Besar Tahun 2008-2012

\begin{tabular}{cccccccc}
\hline TAHUN & $\begin{array}{c}\text { Gedung } \\
\text { SMA } \\
\text { (unit) }\end{array}$ & $\begin{array}{c}\text { Gedung } \\
\text { SMK } \\
\text { (unit) }\end{array}$ & $\begin{array}{c}\text { Gedung } \\
\text { ALIYAH }\end{array}$ & $\begin{array}{c}\text { Gedung } \\
\text { SLTP } \\
\text { (unit) }\end{array}$ & $\begin{array}{c}\text { Gedung } \\
\text { SD/MI } \\
\text { (unit) }\end{array}$ & $\begin{array}{c}\text { Regroping } \\
\text { (unit) }\end{array}$ & Jumlah \\
\hline 2008 & 2 & 1 & 1 & - & 4 & - & $\mathbf{8}$ \\
2009 & 2 & 1 & - & - & 2 & - & $\mathbf{5}$ \\
2010 & 2 & - & - & - & 2 & - & $\mathbf{4}$ \\
2011 & 3 & 1 & - & - & - & - & $\mathbf{4}$ \\
2012 & 1 & - & - & 1 & 2 & - & $\mathbf{4}$ \\
\hline Jumlah & $\mathbf{7}$ & $\mathbf{3}$ & $\mathbf{1}$ & $\mathbf{1}$ & $\mathbf{1 0}$ & $\mathbf{0}$ & $\mathbf{2 5}$ \\
\hline
\end{tabular}

Sumber: Dinas Pendidikan Kabupaten Aceh Besar, 2013

Selain itu, juga telah direalisasikan beberapa program pembangunan sektor pendidikan dan sarana penunjangnya yaitu:

a. Penyediaan tanah pembangunan gedung SMA unggul seluas 10,5 hektar tahun 2012

b. Remedial Teaching kepada siswa SMP/MTS dan SMA/SMK/MA yang dilakukan setiap tahun terealisasi sebanyak 5 kali selama periode 2008-2012

c. Telah disusun Standar Minimal Penyelenggaraan PAUD di kabupaten Aceh Besar

d. Workshop penguatan kinerja komite sekolah sebanyak 5 kali (setiap tahun sebanyak 1 kali)

e. Pendampingan penyusunan Rencana Kerja Sekolah (RKS) sebanyak 10 kali

f. Workshop manajemen berbasis sekolah sebanyak 3 kali

g. Parenting pendidikan anak usia dini

Tabel 10. Realisasi Peningkatan Sarana Prasarana Penunjang Bidang Pendidikan Kabupaten Aceh Besar Tahun 2008-2012 (Unit)

\begin{tabular}{ccccccc}
\hline TAHUN & $\begin{array}{c}\text { Pembangun } \\
\text { an Lab. IPA }\end{array}$ & $\begin{array}{c}\text { Pembangun } \\
\text { an Lab. } \\
\text { Komputer }\end{array}$ & $\begin{array}{c}\text { Pembangun } \\
\text { an } \\
\text { Perpustaka } \\
\text { an SD }\end{array}$ & $\begin{array}{c}\text { Pengadaa } \\
\text { n Alat } \\
\text { Peraga } \\
\text { Pendidika } \\
\mathbf{n}\end{array}$ & $\begin{array}{c}\text { Pengadaan } \\
\text { komputer } \\
\text { SMP dan } \\
\text { SMA }\end{array}$ & $\begin{array}{c}\text { Pengadaa } \\
\mathbf{n} \text { buku } \\
\text { pelajaran }\end{array}$ \\
\hline 2008 & 1 & 2 & 4 & 20 & 25 & 1,000 \\
2009 & 3 & 5 & 1 & 10 & 25 & 1,000 \\
2010 & 2 & 3 & 2 & 35 & 25 & 1,000 \\
2011 & 4 & 6 & 1 & 12 & 30 & 1,300 \\
2012 & - & 4 & 2 & 12 & 15 & 700 \\
\hline Jumlah & $\mathbf{1 0}$ & $\mathbf{2 0}$ & $\mathbf{1 2}$ & $\mathbf{9 0}$ & $\mathbf{1 2 0}$ & $\mathbf{5 , 0 0 0}$ \\
\hline
\end{tabular}

Realisasi Peningkatan Sarana Prasarana Bidang Pendidikan Kabupaten Aceh Besar Tahun 2008-2012. Dari total realisasi anggaran yang digunakan dalam pembangunan bidang pendidikan khususnya pembangunan fisik, dari data yang diolah yaitu sebesar $32.75 \%$, persentase distribusinya dapat dilihat sebagai berikut. 
Berdasarkan data dapat dilakukan dihitung persentase anggaran pembangunan fisik sekolah secara keseluruhan setiap tahun, untuk realisasi pembangunannya setiap tahun sudah terealisasi $100 \%$, artinya pembangunan bangunan fisik sekolah SD/MI, SMA/AMK/ALIYAH, dan SLTP selesai dilaksanakan dengan anggaran yang ada. Peneliti tidak dapat melihat secara rinci efisiensi per sekolah untuk penyerapan anggarannya, namun secara umum dinilai sudah efisien.

Tabel 11. Penyerapan Total Anggaran Pendidikan Dibandingkan dengan Jumlah Realisasi Anggaran Biaya Pembangunan Fisik Sekolah

\begin{tabular}{ccccc}
\hline TAHUN & $\begin{array}{c}\text { Penyerapan Total } \\
\text { Bidang Pendidikan }\end{array}$ & $\begin{array}{c}\text { Jumlah Realisasi } \\
\text { Anggaran Biaya } \\
\text { Pembangunan } \\
\text { Fisik Sekolah }\end{array}$ & $\begin{array}{c}\text { Proporsi Realisasi } \\
\text { Anggaran Biaya } \\
\text { Pembangunan } \\
\text { Fisik Sekolah yang } \\
\text { diserap (\%) }\end{array}$ & $\begin{array}{c}\text { Realisasi } \\
\text { Pembanguna } \\
\text { n Fisik } \\
\text { Sekolah (\%) }\end{array}$ \\
\hline 2008 & $205,460,727,488$ & $17,924,480,000$ & 8.72 & 100 \\
2009 & $197,455,885,762$ & $12,452,500,000$ & 6.31 & 100 \\
2010 & $245,067,477,920$ & $8,221,531,247$ & 3.35 & 100 \\
2011 & $276,052,165,852$ & $21,308,028,229$ & 7.72 & 100 \\
2012 & $320,633,722,657$ & $21,308,028,229$ & 6.65 & 100 \\
\hline
\end{tabular}

Sumber: Data diolah

Tabel 12. Penyerapan Total Anggaran Pendidikan Dibandingkan dengan Jumlah Realisasi Anggaran Biaya Pembangunan Sarana Prasarana Penunjang

\begin{tabular}{ccccc}
\hline TAHUN & $\begin{array}{c}\text { Penyerapan Total } \\
\text { Bidang Pendidikan }\end{array}$ & $\begin{array}{c}\text { Jumlah Realisasi } \\
\text { Anggaran Biaya } \\
\text { Pembangunan } \\
\text { Sarana Prasarana }\end{array}$ & $\begin{array}{c}\text { Proporsi Realisasi } \\
\text { Anggaran Biaya } \\
\text { Pembangunan } \\
\text { Srana Prasarana } \\
\text { Sekolah yang } \\
\text { diserap (\%) }\end{array}$ & $\begin{array}{c}\text { Realisasi } \\
\text { Pembangunan } \\
\text { Sarana } \\
\text { Prasarana yang } \\
\text { Direalisasikan } \\
(\%)\end{array}$ \\
\hline 2008 & $205,460,727,488$ & $24,308,127,057$ & 11.83 & 100 \\
2009 & $197,455,885,762$ & $39,183,821,172$ & 19.84 & 100 \\
2010 & $245,067,477,920$ & $40,952,701,172$ & 16.71 & 100 \\
2011 & $276,052,165,852$ & $47,026,388,229$ & 17.04 & 100 \\
2012 & $320,633,722,657$ & $18,049,740,000$ & 5.63 & 100 \\
\hline
\end{tabular}

Sumber: Data diolah

Seluruh anggaran diserap 100\% untuk pembangunan sarana prasarana penunjang pendidikan di Kabupaten Aceh Besar setiap tahunnya antara tahun 2008-2012, sehingga dapat dianalisis bahwa penyerapan anggaran pembangunan sarana dan prasarana penunjang pendidikan sangat efisien. Dengan melihat pada hasil pengolahan data di atas maka terdapat besaran anggaran yang diserap untuk 
pembangunan bidang lainnya dalam sektor pendidikan selama periode 2008-2012 sebesar Rp. 993.934.634.344,--. Anggaran ini digunakan untuk pembangunan bidang pendidikan pada program-program seperti pemberdayaan pendidikan pada pendidikan non formal (Dayah), pemeliharaan dayah, kegiatan ekstra kurikuler, program umum, program khusus, beasiswa, PAUD, Penyediaan tanah pembangunan gedung SMA unggul, Remedial Teaching kepada siswa SMP/MTS dan SMA/SMK/MA yang dilakukan setiap tahun, penyusunan Standar Minimal Penyelenggaraan PAUD di kabupaten Aceh Besar, berbagai workshop penguatan kinerja komite sekolah, pendampingan penyusunan Rencana Kerja Sekolah (RKS), workshop manajemen berbasis sekolah dan program lainnya.

Realisasi keluaran tahun 2008 tercapai 100 persen, hal ini dikarenakan dorongan besar dari kepentingan rehabilitas dan rekonstruksi di Aceh Pasca Gempa dan Tsunami sehingga kebutuhan pembangunan sarana pendidikan sangat mendesak. Tahun 2009 pembangunan bahkan melebihi dari keluaran yang diharapkan dimana rasio efektivitas realisasi terhadap rencana sebesar $125 \%$, hal ini disebabkan Pemerintah daerah kabupaten Aceh Besar mendapatkan dana tambahan APBD dari dana otonomi khusus. Sementara tahun 2010 hanya tercapai 80\% hal ini disebabkan pembangunan SLTP tidak terealisasi. Tahun 2011 juga demikian pencapaian menurun hingga hanya tercapai $66.7 \%$, ini disebabkan oleh pembangunan SD/MI tidak terlaksana. Sementara tahun 2012 justru melebihi target realisasi yaitu menjadi $133.3 \%$ ini disebabakan pembangunan tahun 2011 dapat dilanjutkan tahun 2012 dan selesai tepat waktu.

Tabel 13. Anggaran yang Diserap dalam pembangunan Pendidikan di Luar Pembangunan Fisik sekolah dan sarana Penunjang Pendidikan di Kabupaten Aceh Besar Tahun 2008-2012

\begin{tabular}{ccccc}
\hline TAHUN & $\begin{array}{c}\text { Penyerapan Total } \\
\text { Bidang } \\
\text { Pendidikan }\end{array}$ & $\begin{array}{c}\text { Penyerapan } \\
\text { Pembangunan } \\
\text { Fisik Sekolah }\end{array}$ & $\begin{array}{c}\text { Penyerapan } \\
\text { Sarana } \\
\text { Prasarana } \\
\text { Penunjang }\end{array}$ & $\begin{array}{c}\text { Penyerapan } \\
\text { Program Lainnya }\end{array}$ \\
\hline 2008 & $205,460,727,488$ & $17,924,480,000$ & $24,308,127,057$ & $163,228,120,431.00$ \\
2009 & $197,455,885,762$ & $12,452,500,000$ & $39,183,821,172$ & $145,819,564,590.00$ \\
2010 & $245,067,477,920$ & $8,221,531,247$ & $40,952,701,172$ & $195,893,245,501.00$ \\
2011 & $276,052,165,852$ & $21,308,028,229$ & $47,026,388,229$ & $207,717,749,394.00$ \\
2012 & $320,633,722,657$ & $21,308,028,229$ & $18,049,740,000$ & $281,275,954,428.00$ \\
\hline
\end{tabular}

Sumber: Data diolah 
Tabel 14. Target dan realisasi Oucome serta Persentase Pencapaiannya Peningkatan Sarana Prasarana Bidang Pendidikan Kabupaten Aceh Besar Tahun 2008-2012

\begin{tabular}{cccc}
\hline TAHUN & Rencana Target & Realisasi & \% Pencapaian \\
\hline 2008 & 8 & 8 & 100.0 \\
2009 & 4 & 5 & 125.0 \\
2010 & 5 & 4 & 80.0 \\
2011 & 6 & 4 & 66.7 \\
2012 & 3 & 4 & 133.3 \\
\hline
\end{tabular}

Sumber: Data diolah

Pencapaian akses pembangunan pendidikan yang lebih luas di Kabupaten Aceh Besar, pemerintah daerah disamping melaksanakan program dan kegiatan melalui sumber dana APBK, APBA, dan APBN, juga telah melaksanakan kerjasama dengan pihak lain diantaranya FKIP Unsyiah, Universitas Negeri Malang, Universitas Negeri Jakarta, Universitas Negeri Padang, Care International, Plan International, UNICEF, World Vision International, Education International, German Redcross, British redcross, Islamic Relief, Islamic Dvelopment Bank, World Bank, USAid, AusAid, Amourt, Umcor, dan John Hopkins University. Selama kurun waktu tahun 2008-2012 pemerintah daerah telah merealisasikan bantuan beasiswa, baik untuk program umum maupun program khusus. Semua program tersebut telah terealisasi dengan baik sebesar $100 \%$, sehingga dapat disimpulkan bahwa keluaran untuk program pendidikan khususnya program kerjasama dengan pihak ketiga dan pemberian beasiswa sangat efektif dan efisien. Beasiswa telah tepat sasaran dan besarannya sesuai dengan yang direncanakan dalam anggaran dan kepada mereka yang tepat pula sesuai dengan mekanisme pemberian beasiswa dan prosedur seleksi yang telah ditetapkan.

\section{Bidang Kesehatan}

Pada periode tahun 2008-2012, Pemerintah Daerah Kabupaten Aceh Besar telah merealisasikan target-target keluaran yang harus dicapai dalam bidang kesehatan. Upaya pelayanan kesehatan dasar pada tingkat Kecamatan terus ditingkatkan dari tahun 2008 hingga tahun 2012 dengan adanya pembangunan ruang rawat inap pada Puskesmas Non Perawatan menjadi Puskesmas Perawatan (Rawat Inap) sehingga masyarakat bisa mendapatkan pelayanan kesehatan dasar selama 24 jam di 23 kecamatan. Pembangunan poskesdes dalam mendekatkan akses pelayanan kesehatan pada ibu dan anak terus ditingkatkan jumlahnya dari tahun 2008-2012 terlihat pada grafik di bawah ini: 


\section{Gambar 5. Realisasi Jumlah Pembangunan Sarana Pelayanan Kesehatan di Kabupaten Aceh Besar 2007-2012}

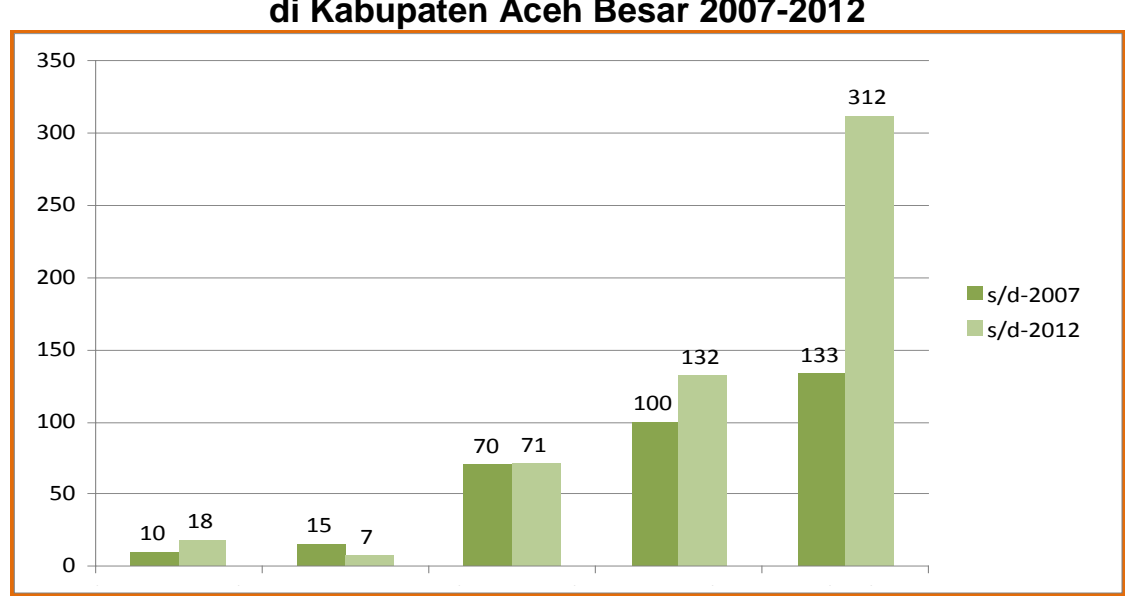

Sumber: Pemda Kabupaten Aceh Besar, 2013

Gambar 6. Realisasi Peningkatan Prasarana Pelayanan Kesehatan di Kabupaten Aceh Besar 2007-2012

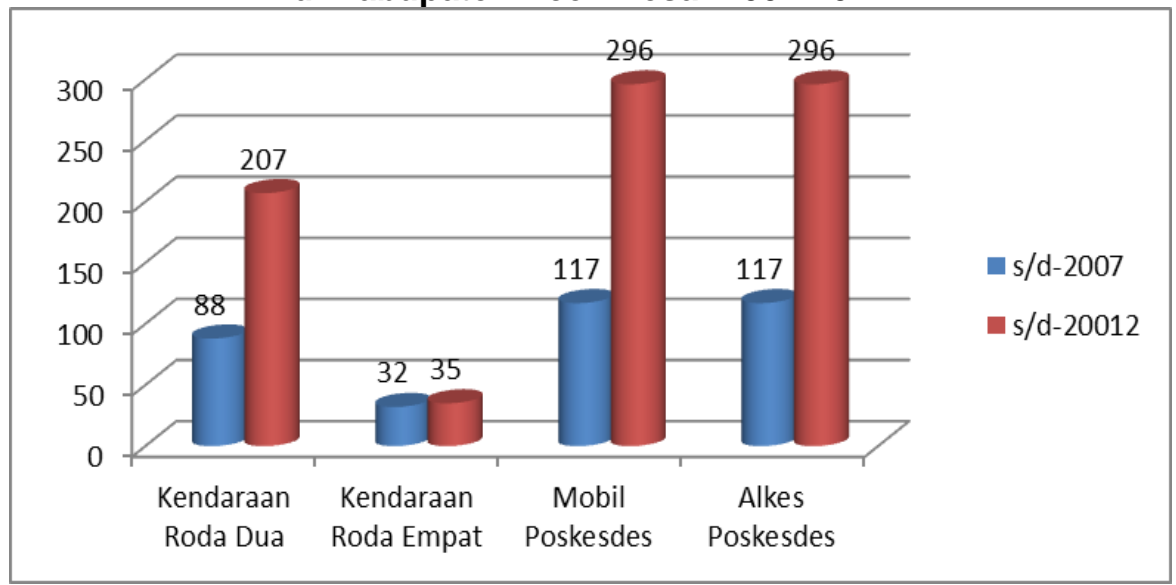

Sumber: Pemda Kabupaten Aceh Besar, 2013

Dalam upaya pemenuhan pelayanan kesehatan rujukan bagi masyarakat di Kabupaten Aceh Besar telah dibangun sebuah Rumah Sakit Umum daerah (RSUD) yang terletak di Kota Jantho, berbagai upaya serta fasilitas yang telah dipersiapkan mulai dari gedung, mobiler, kendaraan, peralatan, tenaga medis dan paramedis. Setiap tahunnya Pemerintah daerah Kabupaten Aceh Besar menganggarkan biaya untuk peningkatan pembangunan gedung, peralatan serta tenaga medis dalam melengkapi fasilitas pelayanan di RSUD tersebut termasuk pemberian beasiswa untuk Dokter Spesialis yang akan selesai masa pendidikannya pada tahun 2012.

Pemanfaatan RSUD Jantho sebagai tempat pelayanan rujukan oleh masyarakat Aceh Besar saat ini masih belum optimal yang disebabkan oleh sulitnya aksesibilitas, untuk mendapatkan pelayanan kesehatan rujukan pasien sering dirujuk langsung ke RSUZA atau RSU Meuraxa banda Aceh yang aksesnya lebih mudah. Terlebih lagi saat ini 
dengan diberlakukannya Jaminan Kesehatan Aceh (JKA) jumlah pasien rujukan semakin meningkatkan, sehingga antrian panjang bagi pasien untuk mendapatkan pelayanan di rumah sakit tersebut, termasuk pasien yang berasal dari Kabupaten Aceh Besar.

Tabel 15. Realisasi Keluaran Perijinan dan Registrasi Tenaga Kesehatan di Kabupaten Aceh Besar 2008-2012

\begin{tabular}{lccccc}
\hline \multicolumn{1}{c}{ Tenaga Kesehatan } & $\mathbf{2 0 0 8}$ & $\mathbf{2 0 0 9}$ & $\mathbf{2 0 1 0}$ & $\mathbf{2 0 1 1}$ & $\mathbf{2 0 1 2}$ \\
\hline Dokter & 37 & 64 & 96 & 128 & 154 \\
Bidan & 136 & 153 & 165 & 238 & 358 \\
Perawat & 5 & 14 & 42 & 86 & 90 \\
Asisten Apoteker & 15 & 29 & 47 & 55 & 60 \\
\hline
\end{tabular}

Sumber: Dinas Kesehatan Kabupaten Aceh Besar, 2013.

Dalam bidang kesehatan, tenaga kesehatan merupakan faktor yang paling penting. Tenaga kesehatan dalam memberikan pelayanan kepada masyarakat harus memiliki kedisiplinan, kemampuan, inovatif dan kreatif sehingga program, kegiatan yang dijalankan akan lebih efektif dan efisien. Di Kabupaten Aceh besar, pada periode 2008-2012 telah dilakukan pemilihan tenaga kesehatan teladan, sebagai bagian dari menumbuhkan motivasi bagi tenaga kesehatan yang lainnya untuk memacu kinerja pelayanan yang lebih baik. Pada sisi lain bidang kesehatan, di Kabupaten Aceh Besar juga telah dilakukan kegiatan perbaikan gizi masyarakat. Berikut ini data kegiatan pemberian vitamin A untuk anak umur 6-11 bulan di kabupaten aceh besar. Cakupan pemberian kapsul vitamin A mengalami penurunan tahun 2008-2009 dari 97,2\% menjadi 94,1\% namun meningkat dari tahun 2009 ke 2010 dan 2011, kemudian menurun di tahun 2012, namun penurunan tersebut tidak signifikan.

Jika dibandingkan dengan target nasional yang hanya $85 \%$ maka pemberian kapsul vitamin A pada bayi usia 6-11 bulan di Kabupaten Aceh Besar sangat berhasil setiap tahunnya. Pada sisi lain, pengendalian penyakit menular juga terus mengalami kemajuan. Jumlah kasus demam berdarah di Kabupaten Aceh Besar mengalami pasang surut setiap tahunnya, sementara itu jumlah penduduk meninggal akibat demam berdarah terus menurun hal ini mengindikasikan bahwa penanganan kesehatan semakin membaik. 


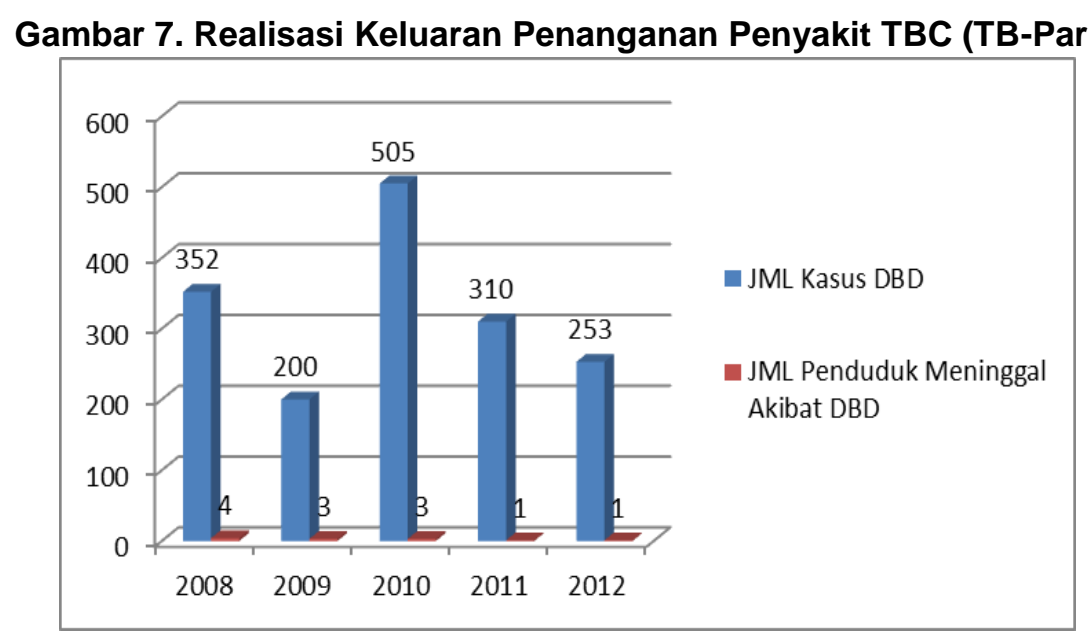

Sumber: Dinas Kesehatan Kabupaten Aceh Besar, 2013.

Penanganan penyakit TBC (TB-Paru) juga terus diupayakan semakin baik. Jumlah penderita dari tahun ke tahun semakin menunjukkan penurunan, hal tersebut dikarenakan pelayanan kesehatan terkait penanganan TBC juga semakin membaik. Berikut data penderita TBC di Kabupaten Aceh Besar Tahun 2008-2012.

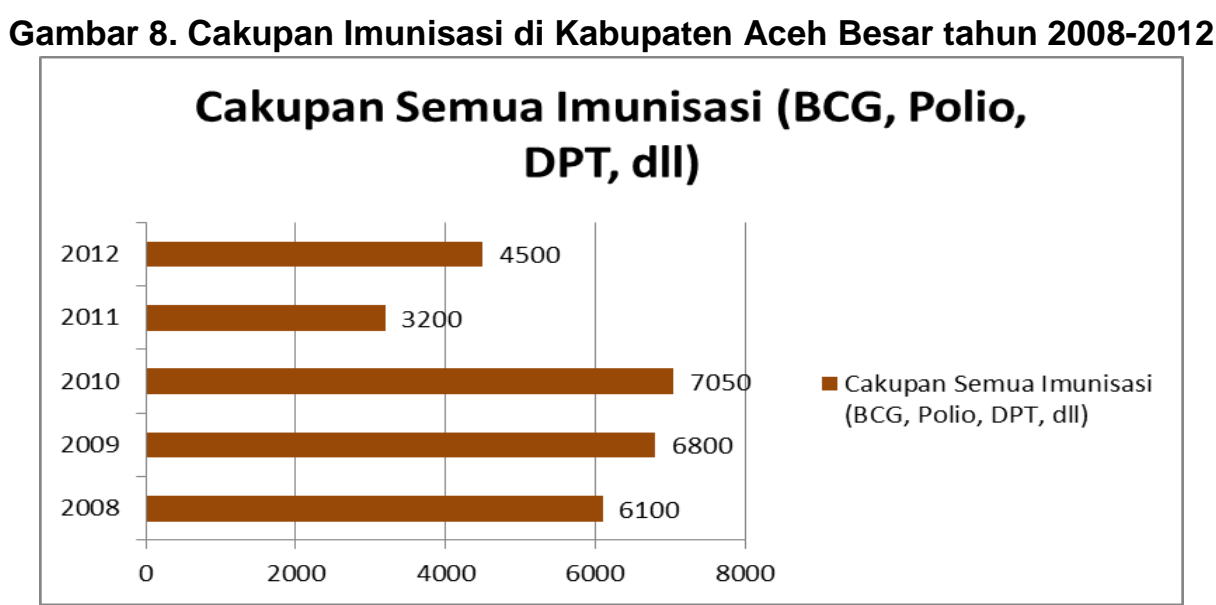

Sumber: Dinas Kesehatan Kabupaten Aceh Besar, 2013.

Gambar 9. Tingkat Perkembangan Strata Posyandu di Kabupaten Aceh Besar 2008-2012

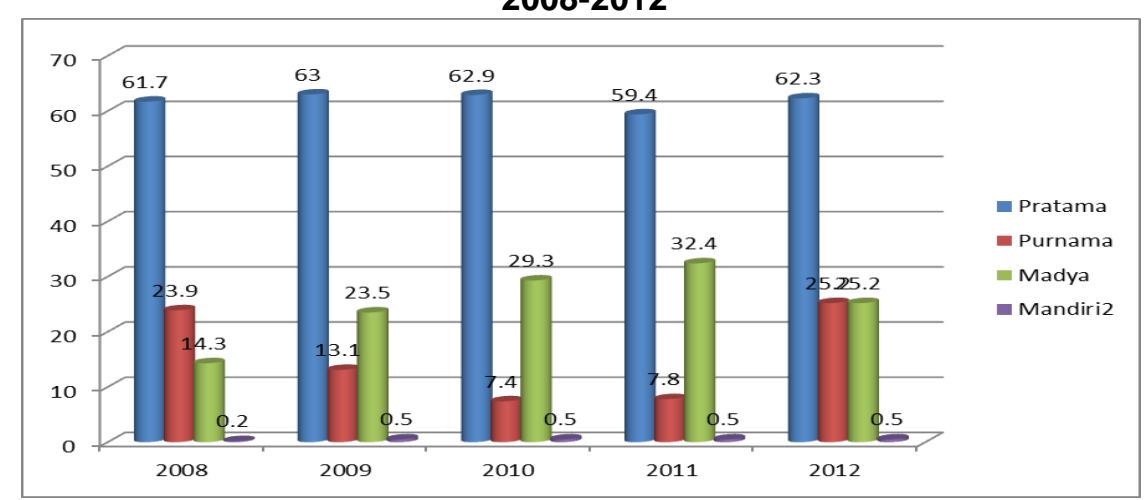

Sumber: Dinas Kesehatan Kabupaten Aceh Besar, 2013. 
Dalam hal kesehatan lingkungan, pemerintah daerah Kabupaten Aceh Besar melakukan pengawasan kualitas air bersih dengan meningkatkan sarana air bersih. Jumlah sarana air bersih secara umum diawasi kualitas air bersihnya sekitar 35\% dari jumlah keseluruhan sarana air bersih. Apabila dibandingkan dengan target nasional untuk pengawasan kualitas air adalah $>70 \%$. Dengan demikian maka pengawasan kualitas air di Kabupaten Aceh Besar masih rendah.

Untuk program kesehatan Ibu dan Anak, Pemerintah daerah telah merealisasikan program tersebut pada seluruh wilayah kecamatan, hingga tingkat Kelurahan dan Desa. Secara keseluruhan target keluaran yang direncanakan belum tercapai secara maksimal, namun demikian jika dilihat secara rata-rata kinerja pencapaian target realisasi keluaran kesehatan Ibu dan Anak sudah baik melalui beberapa indikatornya yakni K1, K2, Linakes, dan Kunjungan Neonatus. Adapun target dan realisasi keluaran Program Kesehatan Ibu dan Anak di Kabupaten Aceh Besar Tahun 2008-2012 dapat dilihat pada Tabel 16.

Tabel 16. Rata-rata Realisasi dan Target Keluaran Program Kesehatan Ibu dan Anak di Kabupaten Aceh Besar Tahun 2008-2012

\begin{tabular}{llcc}
\hline \multicolumn{1}{c}{ Program } & \multicolumn{1}{c}{ Indikator } & Rata-rata Target & Rata-rata Realisasi \\
\hline Kesehatan Ibu dan & K1 & $95 \%$ & $91 \%$ \\
Anak & K2 & $90 \%$ & $85 \%$ \\
& Linakes & $80 \%$ & $80 \%$ \\
& Kunj & $80 \%$ & $80 \%$ \\
\hline
\end{tabular}

Sumber: Dinas Kesehatan Kabupaten Aceh Besar, 2013.

Indikator linakes dan kunjungan neonatus menunjukkan pencapaian target yang maksimal seperti yang ditargetkan oleh Pemerintah daerah kabupaten Aceh Besar, namun untuk indikator kesehatan Ibu dan Anak K1 dan K2 masing-masing hanya tercapai $91 \% \mathrm{~K} 1$ dari target $95 \%$ dan $85 \%$ untuk K2 dari target $90 \%$. Hal ini secara umum disebabkan oleh akses masyarakat terhadap fasilitas pelayanan kesehatan masih relatif sulit dan jauh terutama di beberapa daerah pedesaaan yang terpencil. Dalam hal pembiayaan untuk program kesehatan Ibu dan anak ini Pemerintah Daerah Kabupaten Aceh Besar juga masih mengalami kendala terutama transfer dari APBN yang sering mengalami hambatan sehingga sering terlambat. Pada program lainnya dalam bidang kesehatan yakni pengadaan obat dan perbekalan di Kabupaten Aceh Besar. 


\section{Gambar 10.}

Perbandingan Realisasi Penyerapan Total, Penyerapan Pembangunan Fisik, Pengadan Obat dan Perbekalan, dan Program lainnya Bidang Kesehatan di Kabupaten Aceh Besar Tahun 2008-2012

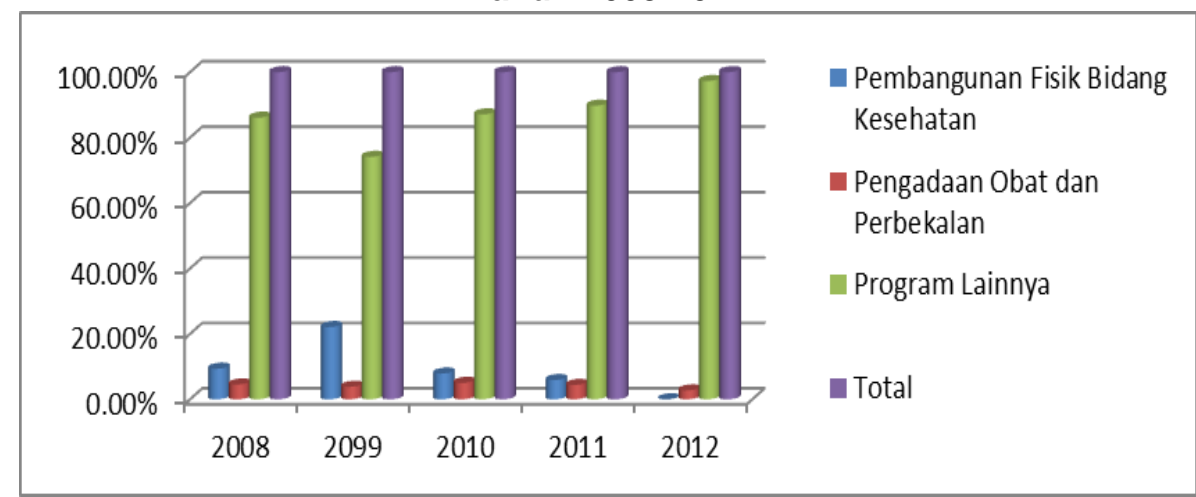

Sumber: Data diolah

Selanjutnya, pembangunan kesehatan di Kabupaten Aceh Besar juga didukung oleh sistem manajemen di dinas Kesehatan Kabupaten Aceh Besar sebagai regulator dan pengendali pembangunan kesehatan, dimana sarana penunjang pada dinas pun terus ditingkatkan. Berikut data target dan realisasi keluaran Sarana Penunjang Dinas Kesehatan Menurut Sumber di Kabupaten aceh Besar tahun 2008-2012.

Tabel 17. Realisasi dan Target Sarana Penunjang Dinas Kesehatan Menurut Sumber di Kabupaten aceh Besar tahun 2008-2012 (dalam unit)

\begin{tabular}{|c|c|c|c|c|c|c|c|c|c|c|c|c|c|c|}
\hline \multirow{2}{*}{ TAHUN } & \multicolumn{2}{|c|}{ Komp } & \multicolumn{2}{|c|}{ Laptop } & \multicolumn{2}{|c|}{$A C$} & \multicolumn{2}{|c|}{ Kamera } & \multicolumn{2}{|c|}{ Handycam } & \multicolumn{2}{|c|}{ Projektor } & \multicolumn{2}{|c|}{ JML T\&R } \\
\hline & $T$ & $\mathbf{R}$ & $\mathbf{T}$ & $\mathbf{R}$ & $\bar{T}$ & $\mathbf{R}$ & $\mathbf{T}$ & $\mathbf{R}$ & $\mathbf{T}$ & $\mathbf{R}$ & $T$ & $\mathbf{R}$ & $\bar{T}$ & $\mathbf{R}$ \\
\hline 2008 & 9 & 9 & 2 & 2 & 12 & 12 & - & - & 1 & 1 & - & - & 25 & 25 \\
\hline 2009 & - & - & - & - & - & - & - & - & - & - & - & - & - & - \\
\hline 2010 & - & - & 1 & 1 & 2 & 2 & - & - & - & - & - & - & 3 & 3 \\
\hline 2011 & - & - & 7 & 7 & 5 & 5 & - & - & - & - & 1 & 1 & 13 & 13 \\
\hline 2012 & 10 & 10 & 1 & 1 & 2 & 2 & 2 & 2 & - & - & - & - & 15 & 15 \\
\hline
\end{tabular}

Sumber: Dinas Kesehatan Kabupaten Aceh Besar, 2013

Dari data tersebut terlihat jelas bahwa semua target pengadaan Sarana Penunjang Dinas Kesehatan Menurut Sumber di Kabupaten aceh Besar tahun 2008-2012 terlaksana $100 \%$, sehingga ini berdampak pada perencanaan, pengorganisasian, pelayanan, pengendalian, sistem manajemen dalam pembangunan kesehatan di Kabupaten Aceh Besar ini semakin membaik dari tahun ke tahun.

Tahun 2009 tidak ada target maupun realisasi pengadaan barang unuk sarana penunjang Dinas Kesehatan Kabupaten Aceh Besar karena penunjang dinas yang ada masih sangat mencukupi dan memadai kondisinya, masih mampu melayani instansi dan layanan kesehatan di ingka kabupaten baik administratif maupun sistem manajemen dan pengendalian. Dengan semakin meningkatnya pembangunan 
kesehatan dan semakin luas dan banyaknya pelayanan dan tugas-tugas admninistratif maka juga terus dilakukan pengadaan untuk tahun 2010, 2011 dan 2012.

\section{SIMPULAN}

Tingkat efektivitas penyerapan anggaran bidang pendidikan dalam Anggaran Pendapatan dan Belanja Daerah (APBD) Kabupaten Aceh Besar, berdasarkan hasil perhitungan dan analisis secara keseluruhan dapat dinilai anggaran bidang pendidikan tidak efektif. Tingkat efisiensi bidang pendidikan berdasarkan hasil perhitungan diperoleh bahwa Rasio Efisiensi Anggaran Bidang Pendidikan dapat disimpulkan bahwa tingkat efisiensi anggaran pendidikan Kabupaten Aceh Besar tahun 2008-2012 kurang efisien.

Penyerapan anggaran masih mengalami banyak kebocoran, belum menyentuh program yang direncanakan secara maksimal sehingga keluaran dan hasil yang dirasakan mmasyarakat belum maksimal, hanya jumlah nominal anggarannya yang habis, sementara outputnya kurang maksimal. Tingkat efektivitas anggaran bidang kesehatan dapat disimpulkan bahwa secara rata-rata kurang efektif. Pada sisi lain tingkat efisiensi anggaran kesehatan menunjukkan variasi, dimana hasil perhitungan menunjukkan bahwa Rasio Efisiensi Bidang Kesehatan setiap tahun kurang efisien dan tidak efisien.

\section{PUSTAKA ACUAN}

Mahmudi. 2007. Manajemen Kinerja Sektor Publik. Yogyakarta : UPP STIM YKPN.

Mardiasmo. 2004. Otonomi dan Manajemen Keuangan Daerah. Yogyakarta: Penerbit Andi Offset.

Mardiasmo. 2009. Akuntasi Sektor Publik. Yogyakarta: Penerbit Andi Offset.

Siagian, S.P. 1984. Filsafat Administrasi. Jakarta: Gunung Agung.

Undang-Undang RI Nomor 32 tahun 2004 tentang Pemerintahan Daerah.

Undang-Undang RI Nomor 33 tahun 2004 tentang Perimbangan Keuangan antara Pemerintah Pusat dan Daerah.

Peraturan Pemerintah Nomor 58 tahun 2005 tentang Pengelolaan Keuangan Daerah.

Peraturan Menteri Dalam Negeri RI Nomor 13 tahun 2006 yang direvisi menjadi Nomor 59 Tahun 2007 tentang Pedoman Pengelolaan Keuangan Daerah. 